\title{
Identification of Donors and Molecular Characterization of Corynespora cassiicola Causing Fungal Leaf Spot of Mungbean and Urdbean
}

\author{
Sushmita V.T. ${ }^{1}$, Meenakshi Arya ${ }^{1 *}$, P.P. Jambhulkar ${ }^{1}$, Manjunatha N. ${ }^{2,3}$, Anshuman \\ Singh ${ }^{1}$ and S.K. Chaturvedi ${ }^{1}$
}

${ }^{1}$ Rani Lakshmi Bai Central Agricultural University, Jhansi, India

${ }^{2}$ ICAR-Indian Grassland and Fodder Research Institute, Jhansi, India

${ }^{3}$ National Research Centre on Pomegranate, Solapur, India

*Corresponding author: meenakshirlbcau@gmail.com (ORCID ID: 0000-0003-4361-2325)

Paper No. 909

Received: 20-04-2021

Revised: 29-05-2021

Accepted: 10-06-2021

\begin{abstract}
In the wake of changing climatic scenario, dimnishing natural resources and growing food demands, the availability of germplasm capable to withstand biotic and abiotic pressures is crucial to ensure sustainability in agriculture system. Among the biotic stresses, fungal leaf spot disease cause significant yield reduction in mungbean (Vigna radiata L.) and urdbean (Vigna mungo L.), which are predominently grown in India and many parts of South and Southeast Asia. The present investigation was designed to identify resistant donors against the fungal leaf spot in mungbean (200) and urdbean (100) accessions by phenotyping under natural field conditions during kharif 2019. Though none of the 200 mungbean lines were found resistant to fungal leaf spot, 8 lines displayed moderate resistance. Likewise, out of 100urd bean accessions three germplasm lines unveiled resistance and 6 moderate resistance against the disease leaving others suceptible to highly sucepetible. The DNA of pathogen causing fungal leaf spot were isolated (Jhansi isolate) from the fungal mycelium and infected plants, respectively for molecular characterization and it was amplified using published primers for ITS and $\beta$-tubulin region for sequencing. A phylogenetic analysis of ITS sequence of the Jhansi isolates along with the reference sequences from NCBI, GenBank revealed maximum identity (98.53 per cent) of isolate with Corynespora cassiicola of cowpea reported from Ghana. Further $\beta$-tubulin sequence also showed 88.55 per cent similarity with C. cassiicola isolate from China. This was further confirmed by leaf sensitivity test against crude fungal toxin cassicoin secreted by C. cassiicola.
\end{abstract}

\section{HIGHLIGHTS}

- Molecular characterization of Corynespora cassiicola infecting mungbean and urdbean in India.

0 Identified few mungbean and urdbean germplasm lines resistant against leaf spot induced by Corynespora.

Keywords: Germplasm, Screening, Resistant, Susceptible, Phenotyped and Corynespora cassiicola

Mungbean (Vigna radiata L., greengram) and urdbean (Vigna mungo L., black-gram) are important short duration grain legumes with wide adaptability, low input requirement and have the ability to improve soil fertility by fixing atmospheric nitrogen. (Karamany 2006; Bhanu et al. 2017). These crops are well adapted in large number of cropping systems and constitute a major source of protein in many developing countries worldwide. India

How to cite this article: Sushmita, V.T., Arya, M., Jambhulkar, P.P., Manjunatha, N., Singh, A. and Chaturvedi, S.K. 2021. Identification of Donors and Molecular Characterization of Corynespora cassiicola Causing Fungal Leaf Spot of Mungbean and Urdbean. IJAEB, 14(2): 265-276.

Source of Support: RLBCAU, Jhansi; Conflict of Interest: None 
produced 2.64 and 2.38 million tonnes of mungbean and urdbean, respectively in the year 2020-21 $\left(3^{\text {rd }}\right.$ Advance Estimates, DAC \& FW, 2020-21).

Although Uttar Pradesh is one of the major states contributing to the total production of mungbean and urdbean in India, their production is stagnant over the last few years due to frequent invasion of insect pests and fungal, bacterial and viral diseases besides drought, water logging, salinity, vagaries of climate etc. Although disease management practices, including physical, chemical, and biological methods have been researched and described in the literature, few of these are available or have been used by growers (Pandey et al. 2018). Over the last few years, resistance breeding has emerged as one of the most effective ways to manage biotic stresses in an economical, eco-friendly and sustainable manner. However, resistance breeding requires continuous efforts of enriching the reservoir of required genes to effectively tackle the specific diseases (Vasudevan et al. 2014). Further, higher temperatures and erratic weather pattern are likely to change the geographical pathogen distribution. This in turn might decrease the effectiveness of existing resistance genes in crop varieties (Garrett et al. 2006; Milus et al. 2009; Vasudevan et al. 2014) by promoting more aggressive races of pathogens and thus fostering chances of breakdown of resistance. Therefore, identification of resistant sources focused on developing varietal lines resistant to pests and diseases is a continuous process (Akhtar et al. 2011) and could be region specific for adaptation to different agro-ecosystems (Sharma and Ortiz 2002).

Leaf spot is an important fungal disease of mungbean and urdbean leading to significant damage to the production. The disease occurs on other legumes, including cowpea and soybean. Warm temperature, frequent rain, and high humidity favour the development of the disease. Numerous attempts have been made to screen mungbean and urdbean germplasm lines against leaf spot diseases in natural field/artificial conditions in few specific locations (Akhtar et al. 2014; Pandey et al. 2018; Reddi et al. 2018 and Bhaskar 2017). However, not much work has been reported related to evaluation of resistant sources against fungal diseases of mungbean and urdbean from Bundelkhand region, which has a leading position in terms of area and production of pulses in India. The experiment reported here highlights efforts to screen mungbean and urdbean germplasm lines under natural field conditions for identification of resistant lines against fungal foliar diseases for their possible use as resistant donors to develop varieties capable to withstand outbreak of fungal leafspot in the drought prone Bundelkhand region.

\section{MATERIALS AND METHODS}

\section{Seed collection and raising of plants for germplasm screening}

During kharif-2019, 200 mungbean and 100 urdbean accessions were collected from ICAR-National Bureau of Plant Genetic Resources (ICAR-NBPGR), New Delhi and ICAR-Indian Institute of Pulses Research (ICAR-IIPR), Kanpur. The seeds were sown in experimental field of RLBCAU, Jhansi $\left(25.51^{\circ} \mathrm{N}\right.$ and $78.56^{\circ} \mathrm{E}$ at an altitude of $227 \mathrm{~m}$ above mean sea level) in two replications of 4 $m$ row length with a uniform spacing of $45 \mathrm{~cm}$ between the rows and $10 \mathrm{~cm}$ between the plants. Timely watering and fertilizer application as per standard agronomic package were done for proper growth of plants, except plant protection methods. Along with these, known mungbean varieties viz., Samrat and urdbean variety, IPU 2-43, were used as resistant checks. Bundelkhand local was used as susceptible checks for both, mungbean and urdbean crop.

\section{Disease incidence}

The disease incidence in the field was recorded starting from the first appearance of the disease till maturity of crop at a regular interval of 15 days. Ten plants were randomly selected in each row and tagged for regular recording of the observations. Scoring was done based on the disease symptoms using standard rating scale (Manandhar et al. 2016) for fungal leaf spot symptoms, regular recording of occurrence and spread of disease. The entire data were pooled together and the Percent Disease Index was computed from the above scales depending on the disease by using the following formula (Wheeler 1969) and the score was given.

\section{Symptomatology and collection of the samples}

To study the symptoms, regular recording of occurrence and spread of disease was done from 
15 DAS onwards at a regular interval of 15 days till harvesting. Diseased samples were collected from the plants showing severe leaf spot symptoms under field condition and were carefully placed in polythene bags, properly tagged, and brought to the laboratory.

\section{Morphological characterization}

\section{Isolation, purification and identification of the fungal pathogen}

Infected plant parts such as leaves showing typical symptoms of leaf spot were used for isolation of pathogens. The leaves were washed with tap water to remove dust. Then the infected portion of the leaves was cut into small pieces/ bits (2-3 mm) and washed in sterile distilled water for one minute, and then surface sterilized with $1 \%$ Sodium hypochlorite solution for 30 seconds, and rinsed thoroughly thrice with sterile distilled water. The infected pieces were air-dried for few minutes to remove water present on the sample. The diseased bits were then transferred to the Petri plates containing Potato Dextrose Agar (PDA) media under aseptic conditions and incubated at $25 \pm 1^{\circ} \mathrm{C}$ for 4 to 5 days.

The fungal culture was purified by single spore isolation method (Riker and Riker 1936) and was maintained in the laboratory under refrigerated conditions for further studies. The fungi were identified according to cultural characteristics described by Gilman (1957), Barnett and Hunter (1972) and Nelson et al. (1982).

\section{Pathogenicity test}

Pathogenicity test was conducted by inoculating one-month-old plants raised in earthen pots. The fungal suspension was made by adding mycelial discs into sterile distilled water and the suspension was sprayed on plants using hand atomizer. Later, inoculated plants were covered with plastic bags for
12 hours photoperiod to create high humidity for two days. The plants were watered regularly and observed for the appearance of disease symptoms. The pathogen was re-isolated and compared with the original culture.

\section{Molecular characterization}

DNA isolation and quantification: The total genomic DNA was extracted from the mycelial mat of pure fungal culture, obtained from the susceptible genotypes of mungbean (PM 2, SML134 and ML-5) and urdbean (STY-2115, U-135, T-9) grown on potato dextrose broth, using of Cetyl Trimethyl Ammonium Bromide (CTAB) (Murray and Thompson 1980). The quantification of DNA was done by observing it at $260 \mathrm{~nm}$ and $280 \mathrm{~nm}$ wavelength using a UV- spectrophotometer. DNA quantification was done to check its quantity, purity, and intactness.

\section{Primer Synthesis and PCR amplification}

Primer synthesis: The universal primers viz. ITS 1 and ITS 4 for ITS region and Tub aF and Tub aR for $\beta$-tubulin region (White et al. 1990; Glass and Donaldson, 1995; Chethana et al. 2015) published already were synthesised (Table 1) and used for Polymerase Chain Reaction (PCR) amplification of the DNA.

PCR amplification: The extracted DNA was subjected to amplification following standard PCR conditions. The standard components of the PCR mix using Dream taq PCR master mix were used for amplification of DNA. After completion of the PCR amplification, the products were stored at $4^{\circ} \mathrm{C}$ until gel electrophoresis is done.

Agarose gel electrophoresis (Horizontal gel electrophoresis): One per cent gel was prepared by melting $1 \mathrm{~g}$ of agarose in $100 \mathrm{ml}$ of $1 \mathrm{x}$ TAE (Tris buffer) and added 2-3 $\mu$ l Ethidium bromide.

Table 1: Details of primer sequences used for amplifying the DNA

\begin{tabular}{|c|c|c|c|c|}
\hline Primers & & Sequence information & $\begin{array}{l}\text { Annealing } \\
\text { temperature }{ }^{\circ} \mathrm{C}\end{array}$ & $\begin{array}{l}\text { Expected } \\
\text { amplicon size }\end{array}$ \\
\hline ITS & ITS 1 (Forward) & CGGATCTCTTGGTTCTGGGA & $54^{\circ} \mathrm{C}$ & $550 \mathrm{bp}$ \\
\hline \multirow[t]{2}{*}{$\beta$-tubulin } & Tub aF (Forward) & GGTAACCAAATCGGTGCTGCTTTC & $55^{\circ} \mathrm{C}$ & $450 \mathrm{bp}$ \\
\hline & Tub aR (Reverse) & ACCCTCAGTGTAGTGACCCTTGGC & & \\
\hline
\end{tabular}


A sufficient amount of 1x TAE buffer was added in the electrophoresis tank to cover gel up to $10 \mathrm{~mm}$ depth. Each well of the gel was loaded with $8 \mu \mathrm{l}$ PCR products along with $4 \mu$ l loading dye (HIMEDIA) along with $50 \mathrm{bp}$ DNA ladder (HIMEDIA). Electrophoresis was done for about 40-45 minutes under 50 volts. Agarose gel with migrated DNA fragments were visualized under gel documentation (BioRad Laboratories). Further, the amplified products were submitted for sequencing at M/S Eurofins Scientific India Pvt Ltd., Bengaluru, India.

DNA sequencing and Phylogenetic analysis: The amplified products of fungal ITS and $\beta$-tubulin regions were sequenced by Sanger method at M/S Eurofins Scientific India Pvt Ltd., Bengaluru, India. The obtained sequences were deposited in the GenBank, National Centre for Biotechnology Information (NCBI) database and Accession numbers were obtained. The sequences thus obtained were also subjected to nBLAST to find out homology with available nucleotide sequences from the fungal DNA database available at NCBI. The reliable reference sequences retrieved from GenBank and present study sequences for fungal DNA were aligned using the ClustalW program available in MEGA X software (https://www.megasoftware. net/) with default parameters. The phylogenetic tree was constructed by MEGA X software using the Maximum Likelihood method adopting 1000 bootstrap replications (Kumar et al. 2018).

\section{Extraction of fungal crude toxin using acetone for leaf sensitivity test}

The extraction of toxin using acetone was done as per the method adopted by Kumar et al. (2017) with the slight modifications. The fungal pathogen was grown on PDA medium by placing $5 \mathrm{~mm}$ of mycelial plug obtained from the margin of the original culture. From a 20 days old culture, mycelial agar plugs of $7 \mathrm{~mm}$ were excised with the help of cork-borer. About 5 mycelial plugs were kept inside the test tube and $10 \mathrm{ml}$ of acetone was added into the same tube and kept under dark conditions in order to extract the fungal toxin. After $4 \mathrm{hrs}$, the extract was centrifuged at $10000 \mathrm{rpm}$ for 10 minutes. The supernatant was transferred into a tube using a micropipette. The treatments for pathogenicity evaluation of cassiicolin crude toxin extracted from fungal culture are described in Table 2.

\section{Study on plant growth parameters of mungbean and urdbean genotypes}

Data on plant growth parameters was recorded by randomly selecting five plants in each of the genotypes of both mungbean and urdbean at maturity. The mean values of five competitive plants of identified resistant and moderately resistant were averaged and expressed as the mean of the character along with the exhibited range. The characters recorded in the study were plantheight, pod length, number of clusters per plant, number of pods per cluster and seed per pod. Plant height was measured in centimetres $(\mathrm{cm})$ from the base of the plant to the tip at maturity. Number of pods and number of clusters were counted at the maturity stage of the selected plants. Pod length was measured from the base to the tip of the pod in $\mathrm{cm}$. Five pods per plant were randomly selected, threshed separately and the average number of seeds per pod was also calculated.

Table 2: Pathogenicity evaluation of cassiicolin crude toxin extracted from fungal culture

\begin{tabular}{ll}
\hline Treatments & \\
\hline Culture crude suspension dilutions & $1000 \mu \mathrm{l}$ spore suspension $(100 \%)$ \\
& $750 \mu \mathrm{l}$ spore suspension $+250 \mu \mathrm{l}$ distilled water $(75 \%)$ \\
& $500 \mu \mathrm{l}$ spore suspension $+500 \mu \mathrm{l}$ distilled water $(50 \%)$ \\
Extracted Toxin & $250 \mu \mathrm{l}$ spore suspension $+750 \mu \mathrm{l}$ distilled water $(25 \%)$ \\
$10 \%$ acetone $(9 \mathrm{ml}$ acetone $+1 \mathrm{ml}$ water $)$ & Crude suspension \\
Water & Control to confirm only acetone reaction \\
\hline
\end{tabular}




\section{RESULTS AND DISCUSSION}

\section{Symptomatology}

The symptoms due to fungal leaf spot disease were recorded 35 days after sowing when the sympotoms first appeared on the older leaves. Initially small chlorotic spots with necrotic centres appear on the leaves and later, the necrotic spots become light brown and surrounded by a chlorotic halo (Fig. 1 and 2). Finally the infected leaves become dry and drop. The symptoms were quite distinct from the Cerospora leaf spot disease (caused by Cercospora canescens) and later after morphological and molecular characterization, the causal organism for fungal leaf spot was identified as Corynespora cassiicola.

\section{Screening of mungbean germplasm}

200 germplasm lines of mungbean were evaluated for occurrence of fungal leaf spot disease under

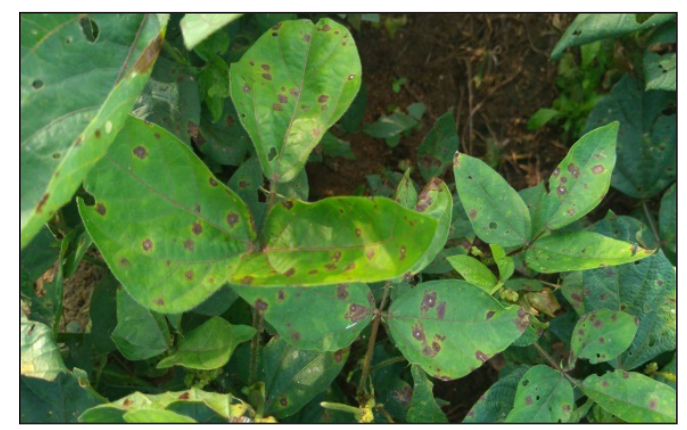

natural environmental conditions prevailing in the region. Scoring for the corynespora leaf spot (LS) disease was done using already available scale (Manandhar et al. 2016). During the present study no germplasm line was found to be resistant to corynespora LS disease. However, eight germplasm lines viz. IC 314322, IC 73401, IC 76499, DGG 5, NM 1, VMS-6, ML 1464 and ML 2037 exhibited moderate resistance (MR) against corynespora leaf spot disease having the disease severity of $33.3 \%$. Of the remaining germplasm lines, 79 were recorded as moderately susceptible (MS) with the disease severity range between 41.7 to 58.3 per cent. Further, in addition to these 79 lines, the check varieties viz. SML 668 and Samrat also showed moderately susceptible reaction to corynesporaLS disease with the disease severity of $58.5 \%$ and $41.7 \%$, respectively. Further, among the identified susceptible lines, few entries viz. IC 314347, IC 348964, IC 314649, Sona Yellow, IPM 312 43K, KM 2241, IPM 2-2-3, CO 8, NH 805, MH 2-15, Pusa Bold

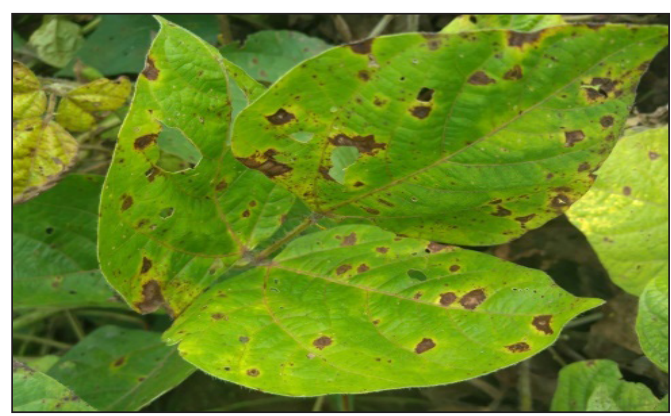

Fig. 1: Symptom of fungal leaf spot on mungbean leaves

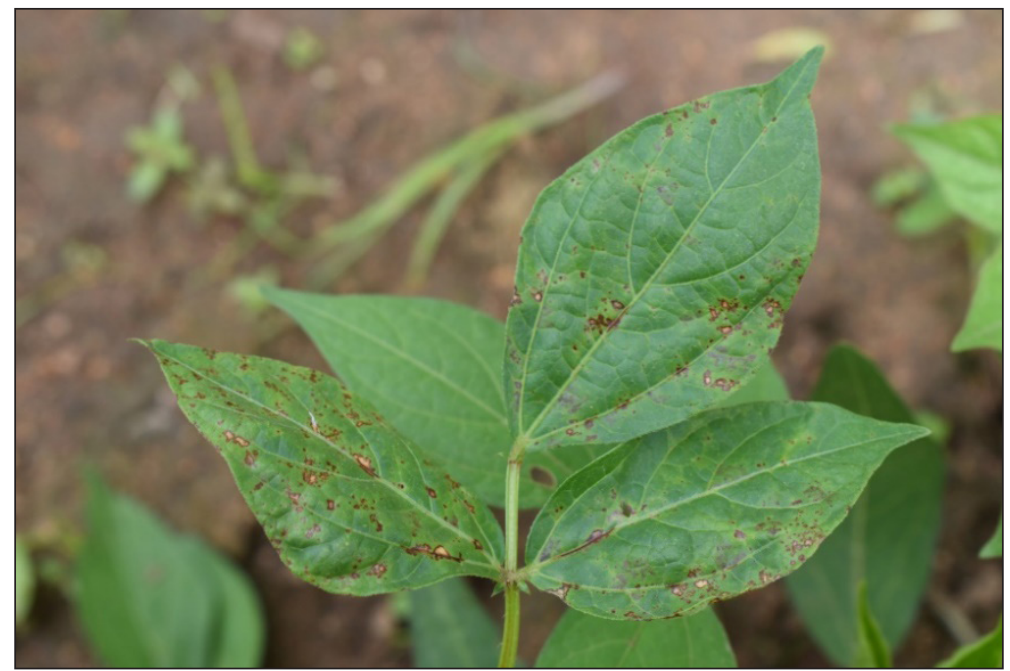

Fig. 2: Symptom of fungal leaf spot on urdbean leaves 
2, PLM 771, IC 76466, IC 285532, IC 76377, PLM 187 and IC 76418 were having the disease severity of $>$ 90 per cent. It was also recorded that a germplasm line viz. IC 305291 was even having the disease severity upto $100 \%$. The disease severity of these lines was even more than the susceptible check (Bundelkhand local) where it was recorded 83.3 per cent only. Therefore, all the screened mungbean germplasm lines were grouped from moderately resistant lines to susceptible lines based on the disease severity. The list of the mungbean entries showing moderately resistant and moderately susceptible reaction to corynespora leaf spot disease is presented in table 3 and rest were susceptible to highly susceptible.

Limited information is available in literature on $C$. cassiicola infecting Vigna pulses, therefore the results were compared with the closely related fungus i.e. Cercospora canescens, belonging to the same phylum, causing fungal diseases on mungbean and urdbean crops with almost similar symptoms (Iqbal et al. 2004; Singh and Gurha 2007; Akhtar et al. 2014). Further, the varied response of the germplasm accessions might be due to more inoculum load of C. cassiicola that prevailed in kharif 2019. The absence of resistant lines may attributed to limited number of germpalsm lines, mostly from north Indian states, included in the present study for screening. The absence of resistant source in the test germplasm therefore highlights clearly the need to have enough genetic material in hand for development of new lines, resistant to disease or bearing specific characteristics. Further, the effectiveness of the genetic resistance also varies with the seasonal changes (Davidson and Kimber, 2007).Therefore, the importance of genetic diversity and biodiversity cannot be emphasized enough in the context of resistence breeding against biotic and abiotic stresses.

\section{Screening of urdbean germplasm}

The corynespora LS disease severity in 100 urdbean germplasm lines was recorded from 16.67 to 100 per cent. Based on mean disease severity three germplasm lines viz. IC-530501, IC-570221 and IC570263 were found resistant to C. cassiicola during kharif, 2019 experiment. The disease incidence of resistant germplasm was recorded in the range of 15.2 to 16.67 per cent as per the scale. Six germplasm lines viz. IC-565276, TPU-99-232, IC 565247, PLU79, PLU81 and IC 41718 were found to be moderately resistant with the disease severity range of 25.0 to 33.33 per cent. Out of 100 germplasm lines that were screened, 39 were found moderately susceptible with disease severity ranging from 41.67 to 58.33 per cent. Remaining 52 germplasm lines were found to be susceptible with disease severity range of 66.67 to 100 per cent. Similar to mungbean lines, the urdbean lines are also grouped from resistant to susceptible lines based on the disease severity and are the entries showing resistant, moderately resistant and moderately susceptible reaction to corynespora leaf spot disease is presented in table 3and rest were found to be suspetible to highly suspetible.

67 urdbean genotypes were screened for C. cassiicola under field condition (Naik et al. 2014) and the accessions TU-94-2, P 703, LBG 709, IPU-02-33, IPU94-2, AKU-2, AKU-99-04, VBN 6 and P 512 showed resistant reaction. However, none of these genotypes were available in the set of the genotypes screened in this study. Similar work on screening of urdbean genotypes against fungal leaf spot was undertaken by several workers (Gunasri et al. 2018; Chandra et al. 2019) where Gunasri et al. (2018) observed out of sixteen genotypes evaluated, only one genotype LBG 645 was moderately resistant to $C$. cassiicola and $C$. canascens. These studies indicated that these crops are being infected by $C$. cassiicola apart from C. canascens. As the disease is comparatively less known in northern and central India, the results obtained on varying reactions against $C$. cassiicola need to be further confirmed in future studies.

\section{Morphological and Molecular characterization}

\section{Morphological characterization}

Initially colony colour was greyish at the centre and whitish towards periphery, brown in the lower surface. Later, the colony colour turned grey in colour. The texture of the fungal colony was fluffy giving the velvety look. The colour of the mycelium varied from white to grey with respect to age of the culture (Fig. 3). The conidia of the fungi were also observed under compound microscope (LEICA DM 2500 LED) at 10X and 40X magnification (Fig. 4). Conidia were hyaline, smooth, septate (5-6), straight or curved and medium to large in size. The size of the conidia ranged from 18-12 $\mu \mathrm{m}$ in length and 6-7 
Table 3: Disease reaction of mungbean and urdbean entries against corynespora leaf spot disease during Kharif 2019

\begin{tabular}{llll}
\hline Reaction & $\begin{array}{l}\text { No. of } \\
\text { entries }\end{array}$ & $\begin{array}{l}\text { Range of } \\
\text { PDI (\%) }\end{array}$ & $\begin{array}{l}\text { Disease } \\
\text { rating scale }\end{array}$
\end{tabular} Entries

\begin{tabular}{lccc}
\hline \multicolumn{4}{l}{ Mungbean entries } \\
\hline MR & 8 & $31.2-33.3$ & 2 \\
MS & 79 & $41.7-58.3$ & 3
\end{tabular}

\begin{tabular}{|c|c|c|c|}
\hline \multicolumn{4}{|c|}{ Urdbean entries } \\
\hline $\mathrm{R}$ & 03 & 15.2- $16.67 \quad 1$ & IC 530501, IC-570221, IC 570263 \\
\hline MR & 06 & $25.00-33.332$ & IC 565276, TPU-99-232, IC 565247, PLU79, PLU81, IC 41718 \\
\hline MS & 39 & $41.67-58.333$ & $\begin{array}{l}\text { NG-2119, UH-8038, NPU-180, UH-85-15, STY-2187, IPU-99-213, IPU-99-123, } \\
\text { IC-16511, STY-2834, IPU-99-221, IPU-99-222, IPU-99-6, JU-78-27, PLU-65, } \\
\text { MASH-1, IPU-917, IC-21003, IPU-98-36, PGRU-95014, K-614830, IC-604265, } \\
\text { IC-530658, IC616487, PLU-53A, IC 605329, PGRU-99028, IC 584696, IC 616493, } \\
\text { IC 545207, IC 616494, IC 570274, IC 616495, IC 530452, IC 545200, IC600266, } \\
\text { PLU54, IC 530611, PDU-8, IPU-99-40 }\end{array}$ \\
\hline
\end{tabular}

IC 314322, IC 73401, IC 76499, NM 1, DGG 5, VMS-6, ML-2037, ML- 1464 IC 314568, IC 121301, IC 417873, IC 488524, IC 19420, IC 15567, IC 373199, IC 76451, IC 103821, COGG 912, ML 2056, PDM 281, ML 1256, PRATEEKSHA NEPAL, PUSA 9531, PAIRY MUNG, MASH 338, RMG-353, SONA GREEN, IPM 5-2-8, IC 76322, IC 305241, IC 8422, IC 305291, IC 121220, IC 52046, LBG 623, IPM409-4, IC 9127-1, IC 76338, IC 76474, IC 314512, IC 52046, IC 314697, IC 39400, IC 121203, PUSA 672, IPM02-3, ML 1299, BDYR 2, HUM 1, MGG295, BM 63, ML 515, IPM 2K 14 9, IPM 99 125, OMG 1030 (PMR), KM11-584, KOPERGAON, OMG-1045(PMR), DAAV-2, IC 11443-1, IC 76414, IC 76361, PL M188, IC 764-76, PLM 1032, PLM 772, PLM 646, PLM 653, IC 76448, IC 314854, PM 6, IC 296672, EC 496839, IC 76389, IC 305284, GANGA 8, BANGLADESH LONG POD, TARM-15, PDM 178, BRAZIL, IPM 2-19, VAMBAN 2, IC 8924, IC 76444
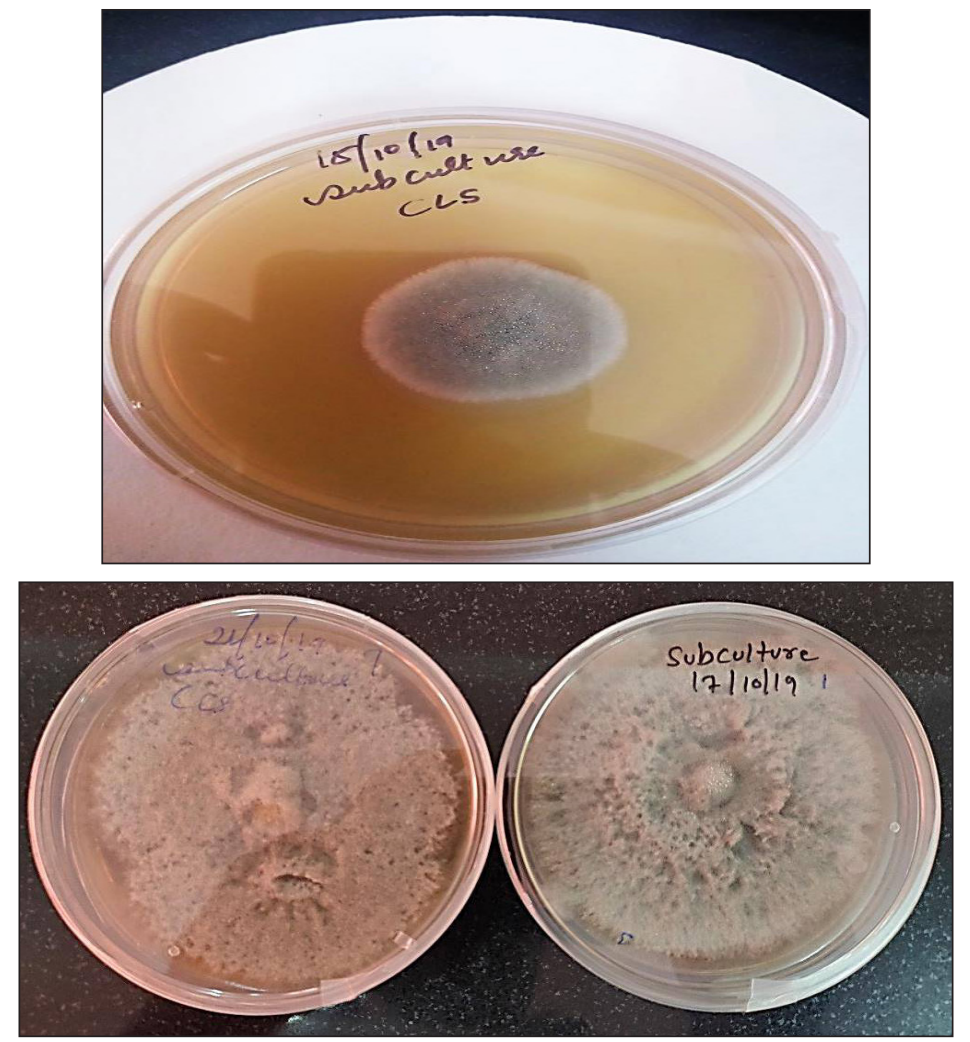

Fig. 3: The growth and texture of the fungal colony of Corynespora cassiicola 
$\mu \mathrm{m}$ in width. The hypha was unbranched, septate with light brown colour. The fruiting bodies of the fungus were amphigenously scattered i.e. were grown on both sides of leaves. The conidiophores were unbranched, and medium dark in colour bearing conidia in chains or singly.

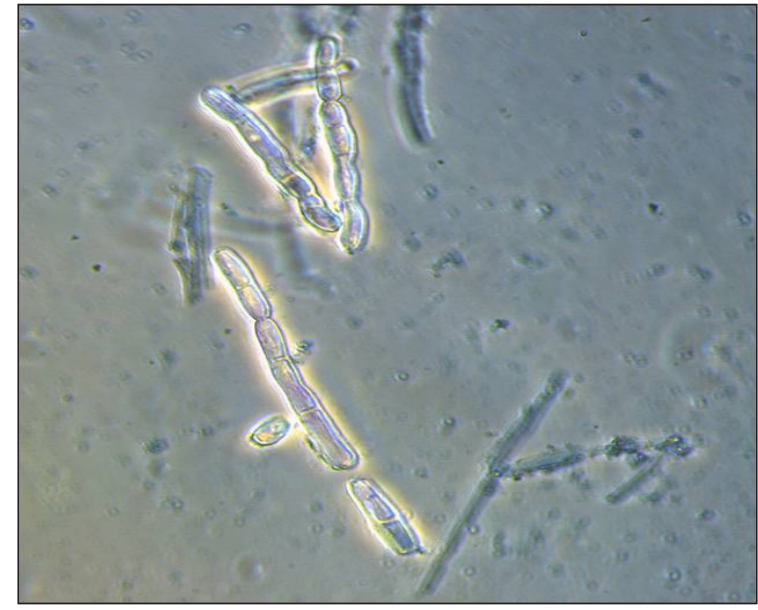

Fig. 4: 40X magnification of microscopic view of condia of C. cassiicola

The morphology of the isolated fungus resembled to that of $C$. cassiicola, which was supported by the morphological study conducted by Souza et al. (2009) of the fungus on the leaf surface of the coffee plant. The similar mycelia and conidial characteristics, as observed in the present study, were also reported in the C.M.I. description of pathogenic fungi and bacteria, in rubber, in chilli, and in tomato for $C$. cassiicola infection (Ellis and Holliday 1971; Qi et al. 2011; Suresh et al. 2017; Kamei et al. 2018). Accordingly, the pathogen causing fungal leaf spot of mungbean and urdbean at Jhansi was identified as $C$. cassiicola confirmed further by pathogenicity test and molecular characterization.

\section{Pathogenicity test}

The pathogenicity test showed jhansi isolate was capable of causing the disease in both the crops. Ferreira and Bentes (2017) have evaluated the pathogenicity of $C$. cassiicola isolates in tomato, eggplant and papaya and found that all isolates caused disease in their original host giving positive reaction. Their study supported the present investigation confirming the Koch's postulate.

\section{Molecular characterization}

The identity of fungal pathogen causing leaf spot disease in mungbean and urdbean was confirmed through molecular approach by subjecting the fungal DNA to PCR amplification using already designed universal primers for ITS and $\beta$-tubulin as described in material and methods. After gel electrophoresis the band size of $550 \mathrm{bp}$ and $450 \mathrm{bp}$ for ITS (Fig. 5) and $\beta$-tubulin (Fig. 6), respectively were observed under gel documentation unit for the selected susceptible genotypes of mungbean and urdbean. The resulting PCR product was sent for sequencing to $\mathrm{M} / \mathrm{s}$ Eurofins Scientific India Pvt. Ltd and the nucleotide sequence for ITS and $\beta$-tubulin region was obtained. The similar findings were reported on molecular characterization studies using ITS for amplification of C. cassiicola infecting cotton (Conner et al. 2013), rubber plants (Prosper et al. 2018), Acanthus ilicifolium (Xie et al. 2020) where the amplicon size of 545- 550 bp were obtained.

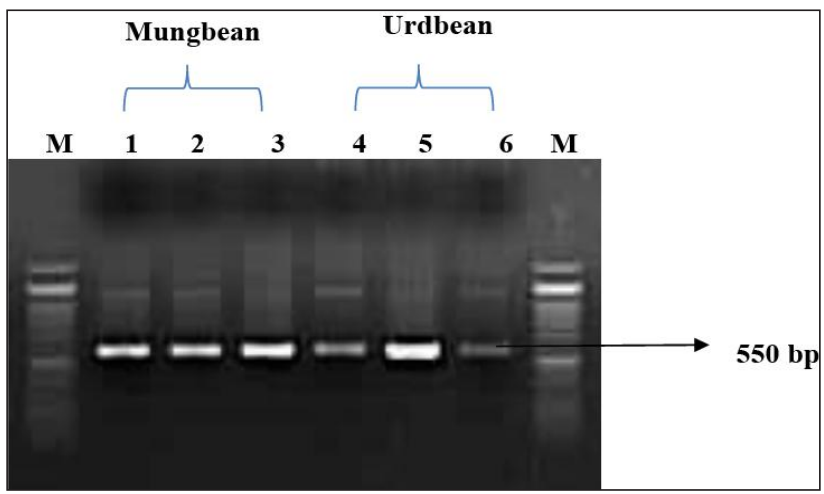

Fig. 5: PCR amplification of DNA of C.cassiicola using ITS specific primers. M: Marker; Lane 1: PM 2; Lane 2: SML134; Lane 3: ML-5; Lane 4: STY-2115; Lane 5: U-135; Lane 6: T-9

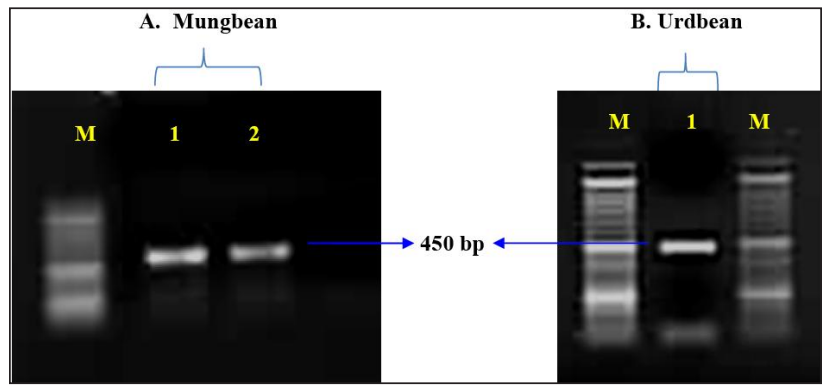

Fig. 6: PCR amplification of DNA of C.cassiicola using $\beta$-tubulin specific primers. (A) M: Marker; Lane 1: PM 2; Lane 2: SML-134 (B) Lane M: Marker; Lane 1: STY-2115; Lane M: Marker

\section{DNA sequencing and Phylogenetic analysis}

The BLAST homology analysis of the amplified ITS and $\beta$-tubulin region sequences was carried out. 
Table 4: C. cassiicola isolates and corresponding GenBank accessions used in the phylogenetic tree analysis based on partial nucleotide sequences of ITS region

\begin{tabular}{llllll}
\hline Original Host & Geographic location & $\begin{array}{l}\text { Name of the } \\
\text { Isolate }\end{array}$ & $\begin{array}{l}\text { Query cover } \\
\mathbf{( \% )}\end{array}$ & $\begin{array}{l}\text { Identity } \\
\mathbf{( \% )}\end{array}$ & $\begin{array}{l}\text { GenBank Accession } \\
\text { number }\end{array}$ \\
\hline Cowpea & Ghana & unid7 & 100 & 98.53 & MN809263 \\
Rubber tree & India & GM & 99 & 97.55 & JX087444 \\
Coleus & USA & RWB321 & 100 & 98.37 & FJ852592 \\
Rubber tree & India & $8 G$ & 100 & 98.19 & JX087446 \\
Rubber tree & Malaysia & CKT05D & 100 & 98.36 & EU364539 \\
Sorghum & China & FXSB-1 & 100 & 98.19 & MK139711 \\
Clinacanthus & Malaysia & SAL1 & 100 & 98.19 & KY806119 \\
Cotton & India & CC7 & 100 & 98.19 & MG976657 \\
Guava & Malaysia & 183PG/F & 100 & 98.36 & GU066725 \\
Rambutan & Malaysia & 118NL & 100 & 98.36 & GU066681 \\
Tomato & USA & AS49 & 100 & 98.19 & FJ852574 \\
Golden trumpet & Brazil & - & 99 & 98.35 & MF962868 \\
Rubber tree & China & CATAS001 & 100 & 98.18 & EF198115 \\
Cotton & India & CICR-NCS & 100 & 98.01 & MN945374 \\
Strobilanthes & Malaysia & PBR5 & 100 & 98.01 & KY828943 \\
Unknown & India & BAB-5556 & 100 & 98.01 & KU504327 \\
Syzygium & Malaysia & 81SS/F & 100 & 98.01 & GU066654 \\
Soybean & Columbia & AGSV13 & 100 & 98.00 & MN298749 \\
Kadsura & China & HLH-1-1 & 100 & 98.00 & MH255527 \\
Avocado & USA & DMW1038 & 100 & 98.00 & KU593529 \\
\hline
\end{tabular}

Table 5: C. cassiicola isolates and corresponding GenBank accessions used in the phylogenetic tree analysis based on partial nucleotide sequences of $\beta$-tubulin (tub A) gene

\begin{tabular}{llllll}
\hline Original Host & Geographic location & $\begin{array}{l}\text { Name of the } \\
\text { Isolate }\end{array}$ & $\begin{array}{l}\text { Query cover } \\
\mathbf{( \% )}\end{array}$ & $\begin{array}{l}\text { Identity } \\
\mathbf{( \% )}\end{array}$ & $\begin{array}{l}\text { GenBank } \\
\text { Accession number }\end{array}$ \\
\hline Rubber tree & China & LC001 & 93 & 88.55 & MN604075 \\
Cowpea & China & JD001 & 93 & 88.55 & MN604072 \\
Papaya & China & FMG001 & 93 & 88.55 & MN564946 \\
Acanthus & China & ALY1-3 & 93 & 88.55 & MN887509 \\
Castor & China & RLT-3 & 93 & 88.55 & MN512639 \\
Avocado & China & YLBB1125 & 93 & 88.55 & MN737729 \\
Cucumber & China & HNLY1707 & 93 & 88.55 & MH763700 \\
Kadsura & China & HLH-1-1 & 93 & 88.55 & MH263734 \\
Kiwifruit & China & BS8 & 93 & 88.55 & KJ954133 \\
Straw berry & China & FCC16 & 93 & 88.55 & KX755447 \\
Golden Privet & China & ST3 & 93 & 88.55 & KX429665 \\
Unknown & USA & EH-1026 & 93 & 88.55 & KU605287 \\
Honey suckle & China & J1 & 93 & 88.55 & KU564092 \\
Sweet potato & China & LP138 & 93 & 88.55 & KU167044 \\
East India lotus & Japan & Nelumbo4 & 93 & 88.55 & AB539201 \\
Cucumber & Japan & KE1 & 93 & 88.55 & AB539181 \\
Perilla & Japan & PC95010 & 93 & 88.55 & AB539172 \\
Mop heads & China & XQ3-1 & 93 & 88.30 & MH572688 \\
Perilla & Brazil & 491 & 93 & 88.31 & HQ641092 \\
Benghal dayflower & Brazil & 631.1 & 93 & 88.57 & HQ641082 \\
\hline
\end{tabular}

The ITS and $\beta$-tubulin region sequences of Jhansi isolate were submitted to NCBI GenBank and the accession numbers MT731034 and MT 647836 were obtained respectively. The ITS nucleotide sequence was found to have 97.55 to 98.53 percent similarity with C. cassiicola infecting different crop species from different geographical locations (Table 4). The ITS sequences of study isolate shared maximum identity $(98.53 \%)$ with C. cassiicola of cowpea (GenBank Accession No. MN809263), reported 
from Ghana. Similarly, $\beta$-tubulin region nucleotide sequences showed maximum nucleotide sequence homology 88.30 to 88.55 per cent with C. cassiicola isolates (Table 5). The majority of $C$. cassiicola isolates reported from different parts of the world showed maximum of $88.55 \%$ nucleotide sequences identity for the $\beta$-tubulin region with Jhansi isolate.

A phylogenetic analysis was also performed of ITS and $\beta$-tubulin sequences along with the reference sequences obtained from NCBI, GenBank. This analysis showed that the Jhansi isolates (MT731034 and MT647836) are placed in the cluster of C. cassiicola and thus supported the findings of morphological identification of the pathogen as $C$. cassiicola. Further, the phylogenetic tree revealed that $C$. cassiicola causing leaf spot in urdbean and mungbean is closely related to $C$. cassiicola isolates of China and Ghana (GenBank Accession No. MN809263 and MN604072, respectively) which were isolated from the cowpea plant (Fig. 7 and 8).

As the morphology, pathogenicity and leaf sensitivity test by cassicolin toxin gave similar results in both mungbean and urdbean genotypes, it was confirmed that the pathogen infecting both

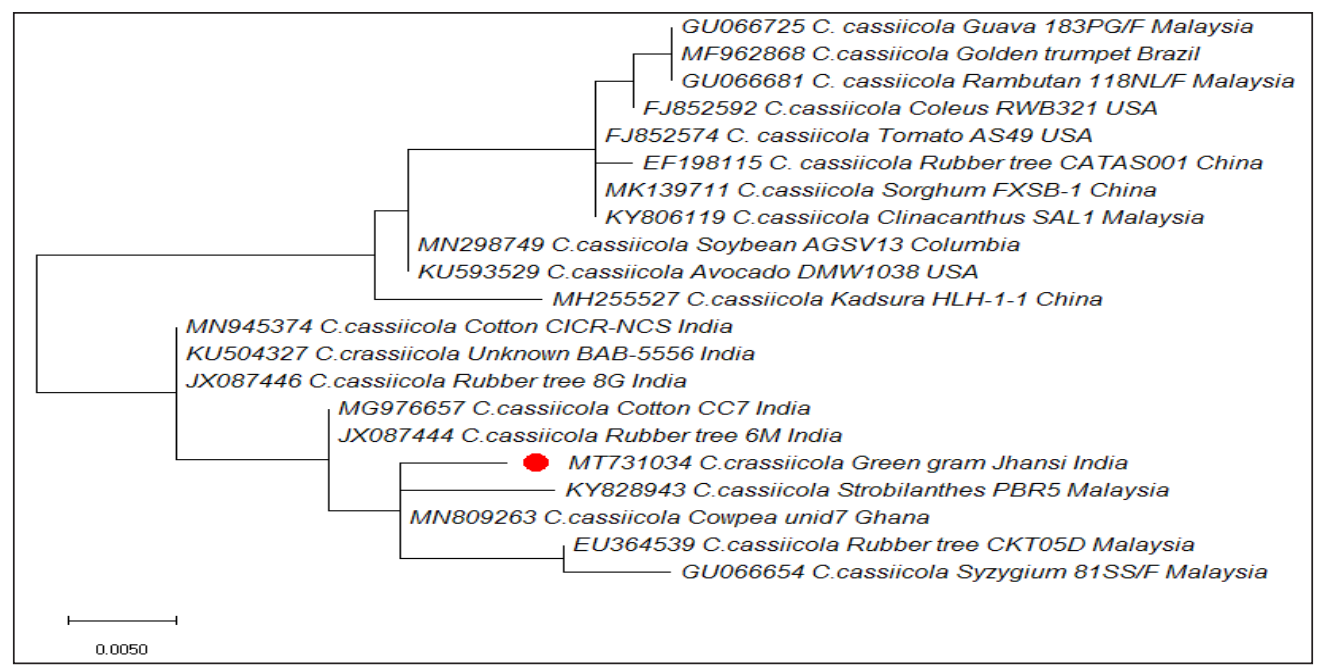

Fig. 7: Maximum likelihood phylogenetic tree generated from ITS region of $C$. cassiicola isolated from mungbean and reference sequences from NCBI at bootstrap values of 1000 replicates (MEGA X)

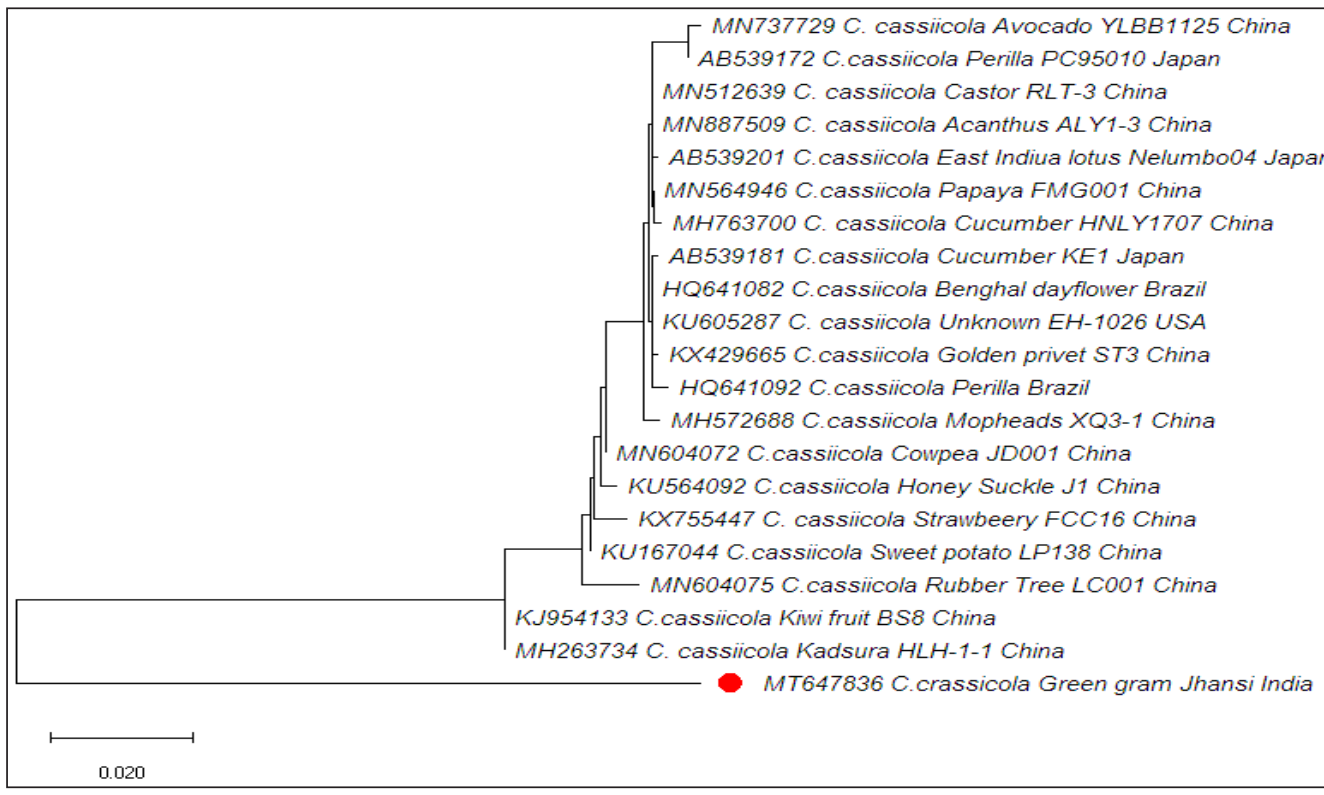

Fig. 8: Maximum likelihood phylogenetic tree generated from $\beta$-tubulin (tub A) region of $C$. cassiicola isolated from mungbean and reference sequences from NCBI at bootstrap values of 1000 replicates (MEGA X). 
these crops is C. cassiicola. Further, there are several reports available for C. cassiicola infecting urdbean (Sontirat et al. 1991; Naik et al. 2014; Gunasri et al. 2018) and no reports are available for molecular characterization of C. cassiicola on mungbean, therefore, the sequencing and phylogenetic analysis was done only for the mungbean genotype for its confirmation at molecular level.

\section{CONCLUSION}

Of the accessions of mungbean (200) and urdbean (100) that were phenotyped under natural field conditions, only 8 lines of mungbean showed moderately resistant reaction while 3 and 6 germplasm lines of urdbean displayed resistant and moderately resistant reaction to the leaf spot disease, respectively.

The pathogen causing fungal leaf spot disease was isolated and characterized morphologically as well as at molecular level. The isolate shared maximum identity (98.53 per cent) with C. cassiicola of cowpea reported from Ghana. Further $\beta$-tubulin sequence also showed the similarity $(88.55 \%)$ with C. cassiicola isolate from China. Based on the screening of the genotypes, the mungbean genotypes viz. IC 314322, IC 73401, IC 76499, NM 1, DGG 5, VMS-6, ML-2037, ML- 1464 and urdbean genotypes, viz. IC 530501, IC-570221, IC 570263, IC 565276, TPU-99-232, IC 565247, PLU79, PLU81, IC 41718 were identified as potential donors against $C$. cassiicola for their use in mungbean and urdbean programme.

\section{REFERENCES}

Akhtar, J., Lal, H.C., Kumar, Y., Singh, P. K., Ghosh, J., Khan, Z. and Gautam, N.K. 2014. Multiple disease resistance in greengram and blackgram germplasm and management through chemicals under rain-fed conditions. Legume Res., 7(1): 101-109.

Akhtar, K.P., Sarwar, G., Abbas, G., Asghar, M.J., Sarwar, N. and Shah, T.M. 2011. Screening of mungbean germplasm against Mungbean yellow mosaic India virus \& its vector Bemisia tabaci. Crop Protec., 30: 1202-1209.

Barnett, H.L. and Hunter, B.B. 1972. Illustrated Genera of Imperfect Fungi. Burgess. Pub. Co., Minnesota, USA., pp. 241.

Bhanu, N.A., Singh, M.N. and Srivastava, K. 2017. Screening mungbean [Vigna radiata (L.) Wilczek] genotypes for Mungbean yellow mosaic virus resistance under natural condition. Adv. Plants Agri. Res., 7(6): 1-4.

Bhaskar, A.V. 2017. Genotypes against major diseases in green gram \& black gram under natural field conditions. Int. J. Curr. Microbiol. Appl. Sci., 6(6): 832-843.
Chandra, S., Rajvanshi, N.K., Kumar, P., Tripathi, R.M. and Chauhan, M.P. 2019. Reaction of urdbean (Vigna mungo) genotypes against cercospora leaf spot (CLS). Int. J. Chemical Stud., 7(3): 439-440.

Chethana, C.S., Chowdappa, P. and Pavani, K.V. 2015. Colletotrichum truncatum and C. fructicola causing anthracnose on chilli in Karnataka state of India. Indian Phytopathology, 68(1): 270-278.

Conner, K.N., Hagan, A.K. and Zhang, L. 2013. First report of Corynespora cassiicola incited target spot on cotton in Alabama. Plant Dis., 97(10): 137.

Davidson, J. and Kimber, R. 2007. Integrated disease management of ascochyta blight in pulse crops. Europ. J. Pl. Pathol., 119: 99-110.

Ellis, M.B. and Holliday, P. 1971. Corynespora cassiicola. CMI Descriptions of Pathogenic Fungi and Bacteria, pp. 303.

Ferreira, A.F.T.A.F. and Bentes, J.L.S. 2017. Pathogenicity of Corynespora cassiicola on different hosts in Amazonas State, Brazil. Summa Phytopathologica, 43(1): 63- 65.

Garrett, K.A., Dendy, S.P., Frank, E.E., Rouse, M.N. and Travers, S.E. 2006. Climate change effects on plant disease: genomes to ecosystems. Annu. Rev. Phytopathol., 44: 489-509.

Gilman, C.J. 1957. A Manual of Soil Fungi. Iowa State College Press: USA. 450. 9.

Glass, L.N. and Donaldson G.C. 1995. Development of primer sets designed for use with the PCR to amplify conserved genes from filamentous Ascomycetes. App. Environ. Microbiol., 61(4): 1323-1330.

Gunasri, R., Kumar, M.V., Kumari, P.V., Sreekanth, B. and Kumar, S.D.V. 2018. Screening of blackgram genotypes for resistance against Corynespora leaf spot \& Cercospora leaf spot. Int. J. Curr. Microbiol. Appl. Sci., 7(11): 1932-1936.

Iqbal, S.M., Zubair, M. and Haqqani, A.M. 2004. Resistance in mungbean to Cercospora leaf spot disease. Int. J. of Agri. Biol., 6(5): 792-793.

Kamei, A., Dutta, S., Sarker, K., Das, S., Datta, G. and Goldar, S. 2018. Target leaf spot of tomato incited by Corynespora cassiicola, an emerging disease in tomato production under Gangetic alluvial region of West Bengal, India. Arch. of Phytopathol. and Pl. Protect., 51: 1039-1048.

Karamany, E.L. 2006. Double purpose (forage and seed) of mung bean production 1- effect of plant density \& forage cutting date on forage \& seed yields of mung bean (Vigna radiata (L.) Wilczck). Res. J. of Agri. E Biol. Sci., 2: 162-165.

Kumar, P., Chand, R., Singh, V. and Pal, C. 2017. In vitro screening of calli of mungbean to cercosporin, a photoactivated toxin. Indian J. Experim. Bio., 55(2): 113-121.

Kumar, R.R., Rajabaskar, D. and Karthikeyan, G. 2018. Screening of greengram (Vigna radiate (L) Wilczek) genotypes against Bemisia tabaci (Gennadius) \& Mungbean yellow mosaic virus in Tamil Nadu. Trends in Biosciences, 11(29): 3580-3587.

Manandhar, H.K., Timila, R.D., Sharma, S., Joshi, S., Manandhar, S., Gurung, S.B., Sthapit, S., Palikhey, E., 
Pandey, A., Joshi, B.K., Manandhar, G., Gauchan, D., Jarvis, D.I. and Sthapit, B.R. 2016. A field guide for identification and scoring methods of diseases in the mountain crops of Nepal. Nepal: NARC, DoA, LI-BIRD and Bioversity International.

Milus, E.A., Kristensen, K. and Hovmoller, M.S. 2009. Evidence for increased aggressiveness in a recent widespread strain of Puccinia striiformis f. sp tritici causing stripe rust of wheat. Phytopathology, 99: 89-94.

Murray, M.G. and Thompson, W.F. 1980. Rapid isolation of high molecular weight plant DNA. Nucleic Acids Res., 8: 19.

Naik, S.G., Adinarayana, M., Kumar, M.V. and Madhumathi, T. 2014. Incidence of Corynespora leaf spot on black gram with other foliar diseases. Int. J. Dev. Res., 4(12): 2587-2591.

Naik, S.G., Adinarayana, M., Kumar, M.V. and Madhumathi, T. 2014. Incidence of Corynespora leaf spot on black gram with other foliar diseases. Int. J. Dev. Res., 4(12); 2587-2591.

Nelson, P.E., Toussoun, T.A. and Marasas, W.F.O. 1982. Fusarium spp. An Illustrated Manual of Identification. The Pennesylvania Univ. Press; Univ., Park, pp. 216.

Pandey, A.K., Burlakoti, R.R., Kenyon, L. and Nair, R.M. 2018. Perspectives \& challenges for sustainable management of fungal diseases of mungbean [Vigna radiata (L.) R. Wilczek var. radiata]: a review. Frontiers Env. Sci., 6: 53.

Prosper, A.K.Y. 2018. Morphological and molecular characterisation of isolates of Corynespora spp, causal agent of "corynespora leaf fall disease" of rubber tree in Côte d'Ivoire. European J. Scient. Res., 148(4): 440-449.

Qi, Y.X., Zhang, X., Pu, J.J., Liu, X.M., Lu, Y., Zhang, H. and Xie, Y.X. 2011. Morphological and molecular analysis of genetic variability within isolates of Corynespora cassiicola from different hosts. European J. Plant Path., 130(1): 83-95.

Reddi, G., Kumar, M.V., Kumari, P.V., Sreekanth, B. and Kumar, S.D.V. 2018. Screening of blackgram genotypes for resistance against Corynespora leaf spot \& Cercospora leaf spot. Int. J. Cur. Microb. Appl. Sci., 7(11): 1932-1936.
Riker, A.J. and Riker, R.S. 1936. Introduction to research on plant disease. John wift Co. Inc. St. Loris, pp. 1176.

Sharma, H.C. and Ortiz, R. 2002. Host plant resistance to insects: An eco-friendly approach for pest management and environment conservation. J. Environ. Bio., 23(2): 111-35.

Singh, R.A. and Gurha, S.N. 2007. Stable source of resistant to cercospora leaf spot in mungbean. Annals of Plant Prot. Sci., 15(2): 501-502.

Sontirat, P., Vonghirunpinyo, L., Choobamroony, W. and Pitakkpaiwan. 1991. Morphology and alternate host of Corynespora cassiicola causing Corynespora leaf spot of rubber. Para Rubber Bulletin, 11: 81-99.

Souza, A.F., Costa, H., Zambolim, L., Mendes, C., Freitas, R. L., Zambolim, E.M., Junior, J.W.C. and Pereira, O.L. 2009. First report of Corynespora cassiicola causing leaf and berry spots on Coffea canephorain Brazil. Aus. Plant Disease Notes, 4: 72-74.

Suresh, V., Sumalatha, N., Ravat, V. K. and Basu, A. 2017. First report of corynespora leaf spot caused by Corynespora cassiicola on chilli in West Bengal, India. Int. J. Curr. Microb. Appl. Sci., 6(8): 3216- 3219.

Vasudevan Kumar, Vera Cruz Casiana M., Gruissem Wilhelm, Bhullar Navreet K. 2014. Large scale germplasm screening for identification of novel rice blast resistance sources. Frontiers in Plant Sci., 5: 505.

White, T.J., Bruns, T.D., Lee, S.B. and Taylor, J.W. 1990. Amplification and direct sequencing of fungal ribosomal RNA Genes for phylogenetics. In: M. A. Innis, D. H. Gelfand, J. J. Sninsky \& T. J. White (Eds.), PCR protocols-a guide to methods \& applications. Academic Press, San Diego, California, pp. 315-322.

Xie, S., He, H., Yang, R., Xu, Z., He, J. and Lu, H. 2020. First report of leaf spot caused by Corynespora on Acanthus ilicifolius in China. Plant Dis., 5(20): 1021. 